\title{
The Muslims' Identity in American Society Through Ayad Akhtar's Play «The Who and the What»
}

\author{
Houaria Chaal \\ Department of English, Hassiba Ben Bouali University, Chlef, Algeria \\ Email address: \\ houariadz@yahoo.fr, h.chaal $@$,univ-chlef.dz \\ To cite this article: \\ Houaria Chaal. The Muslims' Identity in American Society Through Ayad Akhtar's Play «The Who and the What». English Language, \\ Literature \& Culture. Vol. 3, No. 1, 2018, pp. 14-19. doi: 10.11648/j.ellc.20180301.13
}

Received: December 4, 2017; Accepted: January 2, 2018; Published: February 24, 2018

\begin{abstract}
The present research aims to point out the clash between the religious and social aspects of Muslim's life in Ayad Akhtar's debatable play «The Who and the What», in which the author attempts to stir matter of Muslim Immigrants' identity, through an impetuous young Muslim woman, Zarina, who tries to break out all the barrier of her traditional society and heritages which bound her to realize what she wants to do; as a result, she lives in a conflict with her family. However, she was controlled by her rigid father, Afzel, who embodies the old generation. Therefore, Ayad Akhtar intends to depict the tension between the conservative traditional life and modern contemporary American one, exploring the interfaith conflicts. And in order to analyze the novel elements, the study adopts the cultural approach.
\end{abstract}

Keywords: Ayad Akhtar, American Society, Clash, Muslims, Religious Identity, Play

\section{Introduction}

Since the terrorist assaults on the World Trade Center on September 11 th, 2001, in the United States, Islam has been seen as religion of terror, and Muslim immigrants are depicted as violent and terrorists. It is a new age of Islamophobia. Thus, the status of Islam and Muslims in the West, in general and in the U.S. in particular has been an ongoing issue, it is included within media, movies, and literature. So, depending on the slogan saying, 'Being $a$ Muslim bought a pain' and inspiring by his experience, the Pakistani playwright, Ayad AKHTAR, tackles the troubles encountered by the Muslim immigrants who inhabit U.S. Indeed, he attempts to portray the American Muslims' lives literarily, focusing on the Muslims identity in the West, revealing the Western perspective that associates Islam with hostility and aggression, through different literary products, such as; American Dervish, The Invisible Hand, The Who \& the What, and Disgraced.

"The Who and the What" play is about a protagonist, Zarina, who is eager to understand Islam, to know more the Prophet Mohammed ( PBUH). This rebellious modern American Muslim has written a novel portraying the founder of Islam as a real man; she aims to consider "Who He really was" to view Him not just as a figure of worship but as a human. In considering the prophet, Zarina raises questions about the treatment of women under Islam. As a result, this book puts her in conflicts with her father, creating a clash between two different generations in the American society.

\section{The Who and the What}

«The Who \& the What» is a funny new play about identity, religion and the contradictions. It is a debatable play which is viewed as an autobiographical work that reflects the Post 9/11 Era. In one of his interviews, AKHTAR claimed that everything he writes is some version of autobiography. (Trussell, 2014)

So, this literary product incorporates many ideas about religion, the Prophet Mohammed, the traditions, the veil, the family, and the society. In fact, the play turns around a brilliant Pakistani American character, Zarina, who fights and resists strongly, showing the others the real perspective of Muslim women. Even she is a conservative one; she tries to break out all the barrier of her traditional society and heritages which bound her to realize what she wants to do. She lives with her father, Afzal, and her young sister, Mahwish, in modern society which has a wrong idea and perception about Islam and Muslims. The protagonist has written a novel entitled (The Who \& the What) about the 
prophet, evoking the issue of women and Islam.

Zarina has a special mentality, she refuses to get married, rejecting many grooms because she has a love story with someone named "Ryan" who couldn't marry her because he is non- Muslim, for this reason she resigns love. Moreover, this circumstance becomes an obstacle in front of the marriage of her sister; according to the traditions of Pakistani society, the old sister should engage the first. Additionally, Zarina's father attempts to convince her to marry. He has secretly set up a dating-website account for his daughter then he could meet one of these grooms named "Eli", a young convert to Islam. Afzal organizes an appointment with him. They talk about many things especially the story of Eli's convertibility which leads Afzal liked this guy. Later on, Eli and Zarina start meeting and recognizing each other well, so he begins admiring her personality, especially when he knows that she is writing a book about the prophet. Eventually their relationship become trustful, for this reason she decides to wed him year after. Gradually, while her father discovers what the book is really about, he becomes shocked and astonished; he couldn't imagine that her daughter did that, so he rejects her. They spend two years without any contact. At the end of the story, Afzal reconciles her daughter and prays for her, after telling him that she is pregnant. $\mathrm{He}$ gives her some advice to care about her future baby with affection

\section{Religion and Identity Through the Play}

"The Who \& the What" is regarded as a reflection of Muslim's identity struggling between conservative life and modern one. The title signifies the title of Zarina's novel which is a phrase referring to what the prophet Muhammad really is and what we've made for him deeply, she said, "I'm writing a novel about the prophet Muhammad, we know all these things about the prophet or we think we do. Who he was really? We don't know" (The who \& the what, 2014, p.39). And that, of course, reflects the writer's perspective that was declared at the beginning of the play, "Indeed, one of the perplexities of writing this play was the long process of coming to understand the fight at the heart of it; not just that of a daughter with her father, but that of my love and my battle with my heritage, my family, my tradition."(The Who \& the What, $p$. XII)

Ayad Akhtar was influenced by his life experiences in America in a way that he reflects ideas and thoughts by exploring the interfaith tensions in a funny and humor sense, but it has a meaning and depicts a serious issue of Muslim Women. Meanwhile, Akhtar's incisive new drama about love, art and religion examines the chasm between the tradition and the contemporary life concerning American Muslim matrimonial mores. He asks uncomfortable questions of identity and religion in the contemporary world with great intelligence, "Can we belong and yet be separate? Is the process of individuation fundamentally one of loss or gain?"
(The who \& the What, p. XIII). He puts contemporary attitudes towards religion under a microscope, in which he digs deep to confront uncomfortable truths about the ways looking at race, culture, class, religion and sex. In addition, he spots the light on the idea of relationships and the contradictions that identify the identity. Within this play, Akhtar continues not only to dig deeply into his own heritage as a Pakistani-American born into Muslim family, but he has also obsessed with the prophet since he dreamed about him at age of eight, he fully understands Afzal's frenzy but he is also in sympathy with Zarina, 'I'm still trying to understand what the prophet means not only to me but to our community" (Steven, Levingston, 2014, the Washington post). He wants to make each character reveals each identity; these characters portray the struggling with his cultural heritage regarding complex questions while questioning many of the theological and social tenets of his family's Muslim faith, "Is God perfect? Can a feminist obey the teachings of the prophet Muhammad? Should she obey her father? Is the hijab something for a Muslim woman to wear with pride, or does it make her a victim of patriarchal subjugation? All of those questions swirl around "The Who \& the What."

Generally, the play is about a daughter's disagreement with her conservative father over the prophet Muhammad and women in Islam. In the play, the protagonist has written a provocative novel portraying the seventh-century founder of Islam as a real man to view him not just as a figure of worship but as a real human with sexual feelings that eventually influenced attitudes toward women in the Quran. This novel offends her more conservative father and sister, this book creates a conflict within the member of Zarina's family in a point of religion and personal crisis. Her novel depicts an episode from the prophet's life and the circumstances around the revelation of the veil, her procedure is literary, but her challenge is something more than artistic. Moreover, her book takes a hard look at how and why Muslim women came to wear the hijab.

Thus, the curiosity and willingness of Zarina push her to know what's behind the life of the prophet and what the others don't know. Zarina's book is asking some big questions about the prophet Muhammad. Is the Quran really the word of God? Is Allah a woman? But this over excitement and this curiosity put her in troubles with her faith and her conservative family. The play is an imagining of thoughts emotions, desires and doubt about the prophet that might have experienced around the time of one of his marriage with "Zineb Bent Jahch".

Effectively, the play treats the misunderstanding concept about our prophet attempting to understand him more, in which the protagonist is trying to get up the who of the prophet throw various what. Significantly, Akhtar turns an introspective eye on Islam's tough questions like his protagonist, meanwhile, he is so wondering about the true nature of the prophet Muhammad (P.B.U.H). He is trying to write for universal, pushing people to ask deepest questions of their own lives regardless their beliefs, culture and 
religion. He thinks that by doing this play, he opens the audience up to a deeper level of existence, but in way or another, he exaggerates in discussing this sensitive subject which impeaches his religiosity, and all this due to the impact of the contemporary life in America.

\section{Conflicts Representation in the Play}

The play wisely depicts personal, social, cultural, sexual, and religious clashes. Whenever the context changes, the matter changes too.

Indeed, the sisters in "The Who \& the What" are as different as any two sisters with an opposite personality, but mutual respect for their culture. Mahwish looks anxious about Zarina's book because she chooses a provocative and sensitive topic: "women and Islam". This is what confirmed that Zarina has different ways of thinking about religion and traditions, moreover, she doesn't believe in hell because she thinks that it is just a metaphor of suffering of the human being, when she said, "I don't believe in hell."

Mahwish: how are you not scared of hell?

Zarina: I can't be scared of something I don't believe on it. Mahwish: it is in the Quran.

Zarina: it is a metaphor, for suffering for the cycle of human suffering." (The Who \& the What, p.8)

In another context, when talking about love relationship and marriage, Mahwish wants to know her sister's decision about marriage; and then she gets so astonished as Zarina disregards all the traditions.

Mahwish: you're just trying to change the subject again...I can't get married before you do, Zarina.

Zarina: That's absurd. This is not Pakistan.

Mahwish: It's not what 's done.

Zarina: Neither is having anal sex with your prospective husband so that you can prove to his parents you are a virgin when you finally marry him.

Mahwish: I can't believe you just...!!( The Who \& the What, p.6)

Furthermore, Zarina likes writing and she has no time to engage, "my life is fine, leaves me time and space to write (The Who \& the What, p.10). In another way, she wants to occupy herself through writing, in order to forget her first love Ryan, in fact it is just an excuse because she still remembers him. Thus, she considers writing as everything in her life especially when she lost her mother, "all I had was that book, after Mom died, after Ryan, that book was it"(The Who \& the What, p.12). But, these events create an obstacle in front of the marriage of her sister as the old daughter in Pakistan should marry the first according to the Pakistani culture.

Akhtar examines the role of women in Islam through this play in which Zarina is trying to fulfill her free time through doing home works and writing. Her sister said, "you are hiding, Z. behind the cooking, cleaning and "I m working on gender politics"... you have to put Ryan behind you.( The Who \& the What, p. 11). So, Zarina in a way or another tinkered herself to forget her past by doing her duties and respecting her father's decision concerning marriage.

The relationship between Zarina and Eli starts from an arranging appointment, and then they meet each other many times, talking about different subjects among them his family's story and how he is against racism totally. They emphasize also on the convert- American leader "Malcolm"who is affected by him, furthermore, Zarina mentions stories about the prophet written in provocative style; meanwhile, she wants to convince her husband about what she really thinks," the problem, Eli, is that it's in Tabari and alluded to in the Quran. Everyone is always trying to whitewash the sources Anyway. That's how my novel starts. With the prophet seeing, Zaynab naked, with him wrestling with his desire for his son's wife." (The Who \& the What, p.36).

In hand, the tension between the couple raises more when the father tells Eli about Zarina's boyfriend; he picks up the bag and starts to exit. But in another hand, the husband tries to be an open and supportive person who has a tendency to get fired up when he feels there is wrongdoing. He sees the hijab or veil as a symbol of devotion, faith and pride, unlike, Zarina even she is a Muslim, she considers it as a metaphor and she thinks that a woman who wears it wants to be seen like the wives of the prophet, she said," they understand they're turning themselves into metaphorical wives of the prophet". We notice also that Zarina and her mother were unveiled because they refused to wear it even their community is conservative; this is what Afzal said, "Zarina's mother hated the veil. She never wore it. But the structure of that culture, the man at the center, that was in her bones." ( The Who \& the What, p.58)

Indeed, she writes a book about gender politics, in which she talks about the prophet's wives while she spots the light on "Zaynab Bint Jahsh", the seventh wife who was the reason for the revelation of the veil, the curtain and the story with Zayed who was adopted son of the prophet (peace be upon him). When Allah forbid the adoption, Muhammad (P.B.U.H) married Zaynab. This story makes Zarina not really convinced by this idea. She asks Eli, if he knows the story about how the divorce, the prophet saw Zaynab naked ? (The Who \& the What, p.36).

Eli, "the story has been completely discredited."

We deduce that the story is distorted since Zarina ignores the reality of the prophet (P.B.A.H). As a result, this is approved through the Quran:

"And [remember, O Muhammad], when you said to the one on whom Allah bestowed favor and you bestowed favor, "Keep your wife and fear Allah," while you concealed within yourself that which Allah is to disclose. And you feared the people, while Allah has more right that you fear Him. So when Zayd had no longer any need for her, We married her to you in order that there not be upon the believers any discomfort concerning the wives of their adopted sons when they no longer have need of them. And ever is the command of Allah accomplished. (Ahzeb, Verses (36:37)

At this point, Allah insures that the adoption is forbidden through these blessing words, but unfortunately Zarina 
misunderstands this truth because she wants to discover everything deeply related to Islam.

In fact, Zarina has different perception toward Muhammad (P.B.U.H), she really wants to know who really is and what we make for him. She wants also to reveal the hidden things and sees the other side of reality as she is so curious about knowing everything about her religion.

I have this sense of Muhammad, of who he was. We know all this things about the prophet. Or think we do, details: he was an Arab, Aisha was his favorite wife, he had a gap between his teeth, whatever. And all the stories we hear, that have gotten told for hundreds of years, don't point to a real person. It's all like this monument to what we have made of him. But who he really was? We don't know.

(The Who \& the What, P.39)

She asks many questions that shouldn't be asked about religion. This is what let her thinks wrongly about the stories of the prophet (P.B.U.H), she wants to discover everything, but she puts herself in an embarrassed situation with her family. When Eli reads her book, he doesn't agree with her because he thinks that every one reads about the prophet (P.B.U.H) in her book, he will not understand who this man is really. Eli loves the prophet so much, "I didn't recognize the man I fell in love with when I became a Muslim. I mean the man in your book over-whelmed." (The Who \& the What, p.48)

In another context when talking about the prophet, Eli has realized that Zarina hates the prophet; She replied," I don't hate him. I hate the faith does to women. For every story about his generosity or his goodness, there's another that's used as an excuse to hide us. And the story of the veil takes the cake". (The Who \& the What, p50) We can notice that Zarina emphasizes more on how the prophet deals with women in Islam and how she has a wrong idea about his attitudes toward his wife and the veil. So, she raises questions about the treatment of women under Islam.

We deduce that Zarina's book shows that the Quran is the result of all the human things that happened to the prophet, his problem with his wives, community and his own anxieties. In addition to that, Afzal's family is conservative. This is why the father is trying to choose the suitable man for his daughter in order to not make any insanity. In fact, he is arranging her marriage according to their traditions in Pakistan. The father told his daughter about his marriage to convince her by narrating stories about her mother who was a gift even he didn't like her in the beginning of their life. "I don't like her. I just don't like her voice. I don't like her nose..." ( p.26), "I fell in love with that nose! It turned out to be the perfect shape,...her voice, that was the voice of my soul...," "I had different experience of love. My marriage was arranged. And it took time." (p.27) He talks too about his sexual adventures with his wife and that vexes Zarina.

Afzal meets Eli, the future husband, who recognizes him in web site. They talk about several subjects; the important one is the story of his convertibility. So, he admired and was impressed by Eli's personality and quality.

Afzal: "so you run a mosque in cobb country, that you were convert.
Eli: when I was twenty three

Afzal: Massallah, I like you already." (The Who \& the What, p.16).

As it is mentioned above, the religion is the principal issue discussed in this play. It was in different scenes when Zarina, Eli and Afzel speak about a black woman, Ayaan Hirsi Ali, who thinks that all Muslims should be Christians, in truth; both of them are not really convinced by this idea;

Afzel: The one who thinks that all Muslims should be Christians?

Eli: I don't agree with everything she says.

Afzel: She wants us to go running around confused, like Christians!

Eli: Confused!

Afzel: Young man, Jesus Christ was very good man, very important, we know that, Quran is very clear about that, but he was not the son of God. ( The Who \& the What, p. 19)

Afzel: You know she thinks Muslims should all convert to Christianity.

Zarina: She is just saying Christianity has been around longer than we have. It's had more time to work out of the kinks.

Afzel: Believing God can have a son is a sign of working out kinks?

Afzel: Son of God. As if God could have a son.

Zarina: Well, if he's God, he can do anything, right?

Afzel: This is God we're talking about...(p.23)

Additionally, the idea of love is presented in the play. The father, Afzel, is proud of his daughters as they seem good Muslims, but he has no idea about Zarina's writing,"my daughter is good Muslim, she has fifteen biographic of the prophet Muhammad peace be upon him. Fifteen! All lined up in her bedroom". (p.19). For this reason, Afzal doesn't prevent his daughter from dating Ryan before because her mother died and she needs someone who cares about her. When Ryan wants to marry Zarina, her father refused because he is not Muslim and he doesn't want to convert to Islam. Even though Afzal is against love relationships, he allows the relationship between Mahwish and Haroon since they know each other since the childhood. She is always close to her father who is being raised in different culture, sometimes he drives his daughters crazy, but he wants the best for them,"All I care about the two of you. Your happiness, there's only two of you left, after that goddamn cancer too your mother". (p.81). Therefore, Afzal chose Eli as the suitable husband to Zarina; in fact, he did all these things because he really loves his daughters and he always encourages them even he is a conservative man.

Indeed, Afzal is powerful as a patriarch father trying to guide his daughters' lives in traditional way through the chaos of modern culture. He has also traditional dreams for his daughters. When Afzal knows what the book is about Islam and the prophet's life, he becomes mad and disappointed because he totally disagrees with what Zarina has written about Allah and prophet (P.B.A.H). So, Eli and Zarina try to convince Afzal that the book is a metaphor, but he couldn't understand that, considering it as threat for her 
daughter's situation, "This is the prophet! Peace be upon him What did I do to deserve this? Have you lost your mind?"(The Who \& the What, p.76) "You make me regret the day you were born. If anyone sees this, you will never be able to go to Pakistan. Never again."(The Who \& the What, p.77). So, the father is astonished as he considers what she did as a sin that should be punished on, especially, if she is in Pakistan, she will be killed for this. Moreover, Afzal blames Eli since he knows that his wife writes something dangerous about the prophet, but he doesn't stop her, "Call yourself an imam. What kind of Imam doesn't care about his wife writing such things about the prophet?!(The Who \& the What)" However, Eli is torn between his duty as an imam and his loyalty to Zarina. During the conflict, Zarina reveals Mahwish's secrets to her father about doing several relationships with her boyfriend, "what would she think of you having ten years of anal sex so your boyfriend wouldn't break up with you?" (The Who \& the What, p.78) So, the tension raised more and more between the family's members.

It can be noticed that the protagonist is convinced that she doesn't understand many things about her own history and tradition. In fact, she confuses between her traditional Islamic heritage and her new modern American life. She is lost, she ignores: to what does she really belong; either to the tree root or to its leaves? For this, she lives in troubles.

\section{Personal Interpretation}

The play is very important in term of being Muslim in America because there are a lot of misunderstanding and misconceptions about this community. It is a representation of what modern Muslim is like in America. It helps also to put different viewpoints on the American stage. It gets beyond the stereotypes to show the difficulties of modern culture's heritage in the modern life. It could be considered as a real challenge from those Muslims to be or not to be, to show their identity, adapt and being part of them. So, it gives voice and life to stop the marginalization, but in the same time, it deconstructs the expectation and the assumption. Ayad Akhtar treats the events, portraying the life, the position and the revolution of Muslim women, but in a way or another he touches the traditions and humiliated the religion especially the prophet (P.B.U.H). He is attached to the western culture, for this reason he doesn't care about the attitudes and behaviors. As he grew up in a society which marginalized him and regarded him as stranger, that pushed him to explore his ideas and reactions through an audacious writing. Akhtar's dialogue is sharp by navigating the ins and outs of explaining Muslim backgrounds to an American audience. Akhtar wants to show things that reflect the contemporary life, something is faced every day in another land, "It's not like I am trying to be contrarian," Akhtar says. "I am just trying to write to what I think is really happening" (Nelson Pressley: 2016) Effectively, Akhtar encounters this work as a personal psychological or identity issues which are actually expressed in this play. Akhtar, as a screenwriter and artist, has freedom to wrestle his ideas and inspiration without correcting the impression that people have about Islam but to give them an image about it.

Thus, the play is a mirror of Ayad Akhtar personality and his perspective toward Muslim women living in America, in particular. But what makes the receiver astonished is the way of depicting some religious act; it is claimed by Akhtar himself when he said, "An actor will say something and suddenly I'll be shocked that I've written this thing." $\mathrm{He}$ added, "I can't believe it. I want to leave the room."

\section{Conclusion}

Actually, the play provides a unique vital look into the Muslim American experiences during the lens of faith and family; by examining the impact of the host country culture. In fact, it is clear that the Muslim women attempt to integrate themselves into the modern American life with keeping their identity, through the protagonist's interpretations, Zarina, the conservative Muslim lady who has strong roots, but confusing either to be modern American woman or Pakistaniconservative one. This is why she becomes lost; in fact, she represents her religion and faith in a wrong way because of her abnormal curiosity through her book which is about her perspectives toward the prophet and Islam. Thus, she struggles to identify her real identity as a conservative Pakistani Muslim living in modern society. Indeed, Muslim women lost their identity as well as they should be either conservative Muslim or modern American one. It portrays the real challenges that the Muslim women are facing their native identity; meanwhile, this shows the wrong way of thinking of a Muslim woman living in America due to the lack of eruditeness and awareness about religion. So, this literary product probes the universal immigrant story of traditions versus modernity and depicts the tension between sacred and secular in contemporary Muslim life.

\section{References}

[1] Aditi, Sriram. Interview. Ayad Akhtar. Guernica: A Magazine of Art and Politics. Notes for the Stage. June 2, 2014.

[2] Afridi, S, (2001), "Muslims in America: Identity, diversity, and the challenges of Understanding. Carnegie Corporation, New York.

[3] Amaney, Jamal, (2005),"Mosques, Collective Identity, and Gender Differences among Arab American Muslims". Journal of Middle East Women's Studies. Vol. 1, No. 1.53-78: Duke University Press.

[4] Armstrong, K, (1995) Muhammad, London: Victor Gollancz.

[5] Akhtar, AYAD, (2014), The Who \& the What: A Play, Back Bay Books, U.S.A.

[6] Bennett, C. (1992), "Victorian images of Islam". London: Grey Seal.

[7] Benson \& P. Kayal (Eds.), A community of many worlds: Arab-Americans in New York. New York: Syracuse University Press. 
[8] Berner, Heike. Home Is Where the Heart Is? Identity and Belonging in Asian American Literature. Doktor der Philosophie. Fakultät für Philologie. Ruhr-Universität Bochum. 2003.

[9] Bullock, Katherine." ( 2005). Muslim Women Activists in North America; Speaking for Ourselves", University of Texas Press Austin.

[10] Draper, John, William, (1875), "A History of the Intellectual Development of Europe, London". vol.1. 329-330.

[11] Fisher, George, (1996), "The Beginning of Christianity". New York. 25.

[12] Gusdorf, Georges. "Conditions and Limits of Autobiography." Autobiography: Essays Theoretical and Critical. Trans. James Olney. Princeton: Princeton UP, 1980. 30.

[13] Haddad, Y, (2002), Inventing and re-inventing the Arab American identity.

[14] Haddad, Y., \& Lummis, A, (1987), "Islamic Values in the United States". Oxford: Oxford University Press.

[15] Harik, R. \& Marston, E, (1996), Women in the Middle East: Tradition and change. New York: Franklin Watts.

[16] James A. Michener, (1955), "Islam: The Misunderstood Religion' in Reader's Digest". American Edition.

[17] Jawad, Haifaa \&Tansin Benn. (2003). "Book Muslim Women in the United Kingdom and Beyond" Leiden; Boston: Brill.
[18] Jawad. H. (1998) The Rights of women in Islam: An authentic approach, Basingstoke: Macmillan.

[19] Karen, B, (2002). "Islam and toleration: Studying Othoman Imperial Model". International Journal of Politics, Culture and Society.

[20] Kevin, McCarthy \& Maxine, Jones, (1993), "African Americans in Florida": An Illustrated History. Sarasota, FL: Pineapple Press.

[21] Michael, A, Gomez. (1994), "Muslims in Early America." Journal of Southern History.

[22] Shanzad, A. and Khalid, (2008), "US mass media and Muslim world: Portrayal of Muslim by "News Week" and "Time" 1991-2001. European Journal of Scientific Research.

[23] Suleiman, Michael, ed, (1999), "Arabs in America: Building a new Future" Temple: Temple University Press. Understanding". New York: Carnegie Press.

[24] Trussell, Robert. "Kansas City Repertory Theatre Rep Stages Ayad Akhtar Work about the American Experience." The Kansas City Star. The Kansas City Star, 18 Oct. 2014.

[25] Yvonne, Yazbeck Haddad Jane I. Smith Kathleen M. Moore, (2006), Muslim women in America the challenging of Islamic society today. New York: Oxford University Press. 